\title{
ISOLATION AND CULTIVATION OF FUNGAL STRAINS FROM IN VITRO CELL CULTURES OF TWO MARINE SPONGES (PORIFERA: HALICHONDRIDA AND HAPLOSCLERIDA)
}

\author{
Enrique E. Rozas ${ }^{1,4}$, Rodolpho M. Albano ${ }^{2}$, Gisele Lôbo-Hajdu ${ }^{2}$, Werner E.G. Müller ${ }^{3}$, Heinz-C. Schröder ${ }^{3}$, Márcio R. \\ Custódio ${ }^{4}$ *
}

${ }^{1}$ Centro de Energia, Ambiente e Biodiversidade, Escola Superior de Ciências da Saúde, Universidade do Estado do Amazonas, Manaus, AM, Brasil; ${ }^{2}$ Instituto de Biologia Roberto Alcântara Gomes, Universidade do Estado do Rio de Janeiro, Rio de Janeiro, RJ, Brasil; ${ }^{3}$ Institut für Physiologische Chemie, Abt. Angewandte Molekularbiologie, Johannes Gutenberg-Universität, Mainz, Germany; ${ }^{4}$ Departamento de Fisiologia Geral, Instituto de Biociências, Universidade de São Paulo, São Paulo, SP, Brasil.

Submitted: March 01, 2011; Returned to authors for corrections: March 30, 2011; Approved: May 16, 2011.

\begin{abstract}
Despite the large number of reports describing sponge-microbe associations, limited knowledge is available about associated fungi and their relationships with the hosts. In this work, specific fungal strains were obtained directly from in vitro sponge cell cultures (primmorphs) and single sponge cells (cytospins) and compared with those obtained from whole tissue preparations. A total of 27 fungal strains were isolated from the marine sponges Hymeniacidon heliophila and Haliclona melana. Fifteen strains, nine from H. heliophila and six from $H$. melana, were obtained from whole tissue and were considered as possible mesohyl associated or transient fungi. Twelve strains were isolated from in vitro sponge cell cultures (primmorphs) and were, therefore, considered as cell associated. From these, five different strains were obtained from $H$. heliophila isolated cells, while five were identified from cytospins and two from primmorphs of $H$. melana. The fungal strains obtained from cell cultures from both sponge species were different, and none of them were detected in the whole tissue preparations of the same species. Nine H. heliophila and seven H. melana strains shows low similarity with the sequences available in public databases and belong to potentially new species. This is the first report of fungi isolated directly from sponge cells, which allowed the observation and selection of specific strains that probably would not be obtained by usual culture dependent techniques.
\end{abstract}

Key words: Marine sponges, primmorphs, cytospins, fungal detection

\section{INTRODUCTION}

Marine sponges (Porifera) represent one of the oldest extant multicellular animals (20). The more than 8,000 described species inhabit a variety of marine and freshwater systems, from the tropics to Polar Regions (10). They are sessile filter-feeding organisms that influence benthic and pelagic processes by transferring large quantities of material from the water column to the sea floor (25). The sponge body is simple, constituted by an outer epithelial layer (pinacocytes)

\footnotetext{
*Corresponding Author. Mailing address: Rua do Matão. Trav. 14, n. 101. 05508-900. São Paulo, SP. Brazil.; Tel: 55 11 $3091-7611$ Fax: 55 11 3091-8095.; Email: mcust@usp.br
} 
enclosing the mesohyl, formed by specialized cells, extracellular matrix and a network of canals and chambers. In these chambers, water is pumped continuously by flagellated cells (choanocytes) and microorganisms and organic particles are retained and phagocytized (29).

In the last 20 years, sponges have been considered one of the most prolific sources of natural products (see 1, and previous reviews of this series). Several compounds have been isolated and tested, showing a wide range of pharmacological activities such as antimicrobial, cytotoxic, antimalarial, antitumour, antiviral and anti-inflammatory. The chemical diversity is notable, including unusual nucleosides, terpenes, cyclic peptides and alkaloids (31). However, many of these substances are produced by associated microorganisms, and not by the sponge itself. Recently, the isolation, identification and cultivation of this microbiota have been the trend in the search for new compounds (1).

Most sponges harbor large numbers of symbionts, which include bacteria, cyanobacteria, unicellular algae, archaea and fungi, sometimes comprising 40 to $60 \%$ of the total biomass ( 9 , 16). In many cases, these communities are species-specific and independent of the environmentally available strains $(17,42)$. Of the different organisms, bacteria are the most thoroughly investigated and usually reported as participating in the chemical defenses or physiological processes of their hosts (32, $35,37)$.

On the other hand, the knowledge about the diversity and function of potentially sponge-associated fungi is still limited. Despite the growing number of strains identified from sponge samples $(17,18,22,40)$, little evidence has been published to support the idea of true symbioses. The best example of such relationship is represented by unidentified yeast vertically transmitted in three Chondrilla species (19). In addition, several fungi isolated from sponges and other marine substrates were identified as belonging to terrestrial genera. Consequently, even the debate about the real marine origin of these strains is still open $(26,40)$. In general, the fungal strains isolated from marine environments show different secondary metabolite profiles when compared with those from terrestrial habitats. For instance, some marine species of Penicillium produce secondary metabolites unknown to closely related strains of terrestrial origin (15).

In addition to the associated microbiota, as any other marine substratum, sponges are also exposed to large numbers of different microorganisms from the environment. These animals can filter vast quantities of seawater, retaining over $80 \%$ of the suspended particles (23), and therefore a transient microbiota is always present in its canals, tissues and surfaces (24). The presence of these communities, frequently in huge numbers, makes the studies of specific strains especially complex. It can be difficult to distinguish between true spongeassociated microorganisms and environment-derived contaminants, even with the assistance of molecular techniques. Moreover, it is possible that some strains would not be obtained by usual culture-dependent approaches due to overgrowth by other microorganisms. In order to avoid these problems, in this work we use in vitro sponge cell cultures and single cells as initial material to obtain fungal cultures. This approach eliminated most of the mesohyl associated and transient microorganisms, and allowed the focus on the isolation and culture of strains specifically associated to sponge cells.

\section{METHODS}

\section{Sponges}

A total of 12 samplings were performed at Praia Grande

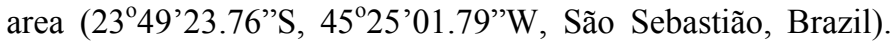
On each occasion, four individuals of Hymeniacidon heliophila Parker, 1910 (Halichondrida: Halichondriidae) and four of Haliclona melana Muricy and Ribeiro, 1999 (Haplosclerida: Chalinidae) were collected. Individual specimens were placed separately into plastic bags and brought to the laboratory in icecooled boxes $\left(18-20^{\circ} \mathrm{C}\right)$. These species have already been used 
in previous works on sponge cell biology $(5,6)$, and showed good responses to culture conditions. Taxonomic identification was performed by M.R. Custódio, using standard methods (21).

\section{Sponge cell culture (Primmorphs)}

Cell dissociation and primmorph formation followed protocols described elsewhere (6). Sponge tissues were cleaned of larger epibionts using forceps, cut in 3 to $4 \mathrm{~mm}$ pieces, washed in seawater and incubated with CMFSW+E (calcium and magnesium-free seawater with EDTA: $460 \mathrm{mM} \mathrm{NaCl}, 7$ $\mathrm{mM} \mathrm{Na}_{2} \mathrm{SO}_{4}, 10 \mathrm{mM} \mathrm{KCl}, 10 \mathrm{mM}$ HEPES, 2.5 mM EDTA, pH 8.2. Sigma) for $30 \mathrm{~min}$ in a low speed rotary shaker. The supernatant was then discarded, and the fragments resuspended in fresh $\mathrm{CMFSW}+\mathrm{E}$ solution. After continuous shaking for $45 \mathrm{~min}$, the supernatant was collected and filtered through a $40 \mu \mathrm{m}$ mesh. The cells were pelleted by centrifugation at $250 \mathrm{x} \mathrm{g} / 10 \mathrm{~min}$ and re-suspended in sterilefiltered $(0.22 \mu \mathrm{m})$ natural seawater from the same collection site, supplemented with antibiotics (kanamycin $100 \mathrm{mg} / \mathrm{L}$, gentamicin $50 \mathrm{mg} / \mathrm{L}$ and tetracycline $10 \mathrm{mg} / \mathrm{L}$, Calbiochem) and phenol red (16 mg/L, Sigma). This media was used for maintenance of the primmorphs. In the first week, it was renewed daily and in the following weeks, each three days.

\section{Isolation and culture of the fungal strains}

The primmorphs were observed daily on inverted microscope, and the fungal hyphae that appeared on the surface were picked and incubated in tubes with DY medium (Dextrose 1\% and Yeast Nitrogen base 1\% (Fluka) in natural seawater). After $24 \mathrm{~h}, 100 \mu \mathrm{l}$ of each suspension was disseminated in DY agar (DY medium with $2 \%$ agar) to verify the purity of the culture. The fungi were carefully selected according to morphologic characteristics $(7,13)$, transferred to $125 \mathrm{ml}$ Erlenmeyer flasks with $60 \mathrm{ml}$ of DY medium and incubated at $20^{\circ} \mathrm{C}$. After 15 days, the cultures were sampled for DNA extraction and identification.

To obtain cell-associated fungi, primmorphs were cultivated for 21 days and then dissociated with CMFSW+E. The cell suspension was counted using a Neubauer chamber, and attached in low density to sterile glass coverslips using a cytocentrifuge $\left(80 \times \mathrm{g} / 5 \mathrm{~min}, 1.5 \times 10^{4}\right.$ cells per spot. Citospin 248, FANEM). The coverslips were allowed to dry in a sterile laminar flow hood for $3 \mathrm{~h}$ and then transferred to six-well plates filled with DY medium, with the cell surface facing the overlaying medium. For each plate, one well with a coverslip prepared with $\mathrm{CMFSW}+\mathrm{E}$ was used as control. Culture observation was carried out using phase contrast inverted microscopy (Eclipse TE300, NIKON), until the mycelia became visible with the naked eye. Morphologically different strains were collected and transferred to the DY agar to verify the purity of the culture, and then cultivated as described above. To differentiate between strains associated with the cells and those incidentally present in the sponge surfaces and canals, fungal cultures were established from sponge whole tissues. Sponge fragments were washed with sterile $\mathrm{CMFSW}+\mathrm{E}(5 \mathrm{~min})$ in order to release peripheral cells and eventual transient fungi, gently compressed and the resulting material was collected in a flask with sterile seawater. Then, $100 \mu \mathrm{l}$ aliquots of this suspension were disseminated in DY and isolates were purified by successive selection and cultivated following the procedure described above.

\section{DNA extraction and polymerase chain reaction (PCR) amplification}

The DNA was isolated from fresh samples $(25 \mathrm{mg})$ of mycelia from the fungal cultures using the PureLink ${ }^{\mathrm{TM}}$ Genomic DNA Kit (Invitrogen). The extracted DNAs were analyzed in $1 \%$ agarose-Tris-borate-EDTA gels to determine the quality and the amount of DNA obtained. Amplification of the $18 \mathrm{~S}$ rRNA gene was performed using the specific primers EF3 (5'-TCCTCTAAATGACCAAGTTTG-3'), EF4 (5'GGAAGGG [G/A] TGTATTTATTAG-3') and Fung5 (5'GTAAAAGTCCTGGTTCCCC-3') (32). One microliter of each DNA sample (100 ng) was used for PCR amplification. 
Primer sets EF4/EF3 and EF4/Fung5 were used for direct amplification of $18 \mathrm{~S}$ rDNA sequences from extracted fungal DNA. PCR mixtures $(50 \mu \mathrm{l})$ for both sets consisted of $1 \mathrm{x}$ PCR buffer (Invitrogen), $2 \mathrm{mM} \mathrm{MgCl}_{2}, 0.2 \mathrm{mM}$ mix of dNTPs, $50 \mathrm{ng}$ of each primer and $0.3 \mu \mathrm{l}$ Platinum Taq Polymerase $(5 \mathrm{u} / \mu 1$, Invitrogen). The following thermocycling pattern was used: $94^{\circ} \mathrm{C}$ for $3 \mathrm{~min}(1 \mathrm{cycle}) ; 94^{\circ} \mathrm{C}$ for $1 \mathrm{~min} ; 48^{\circ} \mathrm{C}$ for $1 \mathrm{~min} ; 72^{\circ} \mathrm{C}$ for 3 min $(35$ cycles $)$; and $72^{\circ} \mathrm{C}$ for $10 \mathrm{~min}(1 \mathrm{cycle})$. The PCR products were separated on a $1 \%$ Agarose-Tris-borate-EDTA gel.

\section{Partial sequencing of the fungal $18 S$ rRNA gene}

The PCR products were purified with the Illustra GFX PCR DNA and the Gel Band Purification Kits (GE Healthcare) and used in cycle sequencing reactions with the kit DYENAMIC ET terminators (GE Healthcare). The $0.5 \mathrm{~Kb}$ fragments obtained from each fungal strain, corresponding to the region amplified by the EF4/EF3 primer set were sequenced with the EF4 primer. The sequencing reactions were analyzed by capillary electrophoresis on a MEGABACE 1000 sequencing platform (GE Healthcare). Consensus sequences were obtained using the CAP3 Sequence Assembly Program (10). Sequences were then manually edited and analyzed by BLAST searches at the National Center for Biotechnology Information (NCBI, accessed in July, 2010). Sequence alignment of the $0.5 \mathrm{~Kb}$ fragments and phylogenetic trees were prepared with POY v4.1.2 (39), using 60 random sequence-addition repetitions and TBR branch swapping using parsimony criterion. The sequence of the anamorphic fungi Acremonium cellulolyticus (accession number BA474750) was used as outgroup. All sequences were deposited in the GenBank, and accession numbers are listed in Table 1.

Table 1. Fungal strains isolated and cultivated from the whole tissue, single cells and primmorphs of Hymeniacidon heliophila (Hy) and Haliclona melana (Ha). Accession numbers (A.N.) and scores (\%) are given. The closest sequence match corresponds to the top BLAST score record (accessed in July 2010).

\begin{tabular}{|c|c|c|c|c|}
\hline \multicolumn{5}{|c|}{ Hymeniacidon heliophila } \\
\hline \multicolumn{2}{|c|}{ Whole tissue } & Closest Sequence Match & A.N. & $\%$ \\
\hline Hy 1 & (FJ477281) & Penicillium waksmanii MMA12 & (HM231102) & 100 \\
\hline Hy 2 & (FJ477282) & Penicillium sp. HB-92 & (AB521044) & 99 \\
\hline Hy 3 & (FJ477279) & Penicillium waksmanii MMA12 & (HM231102) & 99 \\
\hline Hy 4 & (FJ477283) & Penicillium sp. HB-92 & $(\mathrm{AB} 521044)$ & 97 \\
\hline Hy 5 & (FJ477284) & Penicillium sp. HB-92 & (AB521044) & 99 \\
\hline Нy 6 & (FJ477293) & Penicillium sp. HB-92 & (AB521044) & 99 \\
\hline Hy 7 & (FJ477286) & Penicillium sp. HB-92 & (AB521044) & 98 \\
\hline Hy 8 & (FJ477278) & Penicillium sp. ASR-151 & (GU973852) & 98 \\
\hline Hy 9 & (FJ477287) & Penicillium sp. HB-92 & (AB521044) & 96 \\
\hline \multicolumn{5}{|c|}{ Single cells } \\
\hline Hy I & (FJ477273) & Uncultured fungal contaminant & $(\mathrm{EF} 053580)$ & 94 \\
\hline Hy II & (FJ477272) & Cryptosphaeria sp. MYA-4414 & (FJ430577) & 98 \\
\hline Hy III & (FJ477274) & Paraphaeosphaeria sp. B19 & (GQ253350) & 98 \\
\hline Hy IV & (FJ477276) & Ascomycota sp. Mo19 & (EU887770) & 98 \\
\hline Hy V & (FJ477277) & Cryptosphaeria sp. MYA-4414 & (FJ430577) & 97 \\
\hline
\end{tabular}

\begin{tabular}{lr}
\multicolumn{2}{c}{ Haliclona m } \\
Whole tissue \\
Ha 1 & (FJ477280) \\
На 2 & (FJ477292) \\
Ha 3 & (FJ477291) \\
На 4 & (FJ477288) \\
На 5 & (FJ477289) \\
На 6 & (FJ477290)
\end{tabular}

Penicillium sp. ASR-302

Penicillium sp. HB-92

Penicillium sp. HB-92

Penicillium sp. HB-92

Emericella nidulans

Penicillium sp. HB-92

$\begin{array}{ll}\text { (GU973859) } & 97 \\ (\text { AB521044) } & 99 \\ (\text { AB521044) } & 96 \\ (\text { AB521044) } & 99 \\ (A B 008403) & 97 \\ (\text { AB521044) } & 99\end{array}$

Cladosporium cladosporioides Cladosporium cladosporioides Cladosporium cladosporioides Xylaria polymorpha

Uncultured fungus FAS 62

$\begin{array}{ll}(\mathrm{AB} 521051) & 99 \\ (\mathrm{AB} 521051) & 98 \\ (\mathrm{AB} 521051) & 99 \\ (\mathrm{AB} 274816) & 97 \\ (\mathrm{GU} 072561) & 98\end{array}$

\section{Single cells \\ Ha I (FJ477269) \\ Ha II (FJ477267) \\ Ha IV (FJ477270) \\ Ha V (FJ477266)}

Primmorphs 


\section{RESULTS}

\section{Fungal isolation and cultivation}

Five strains were obtained from single cells (cytospins) of each sponge (Table 1). The hyphae of two of these fungi, Ha IV and Ha V (Fig. 1a-f), were detected at early stages, always associated or near the sponge cell nuclei. Both appear as small clusters of round, bright structures from which the adult mycelia originates (Fig. 1a, e). In Ha IV, large amounts of insoluble hyaline material of unknown nature could be observed deposited around the hyphae even at early stages (Fig. 1b, c). In this strain, the hyphae were always embedded in this substance, in which some crystals were formed in later stages (Fig. 1d). In Ha V, the hyphae initially grew following the host cell margins (Fig. 1e) and latter forming a branched, three-dimensional mycelium (Fig. 1f). Such very early stages of other strains were not detected, and they were observed already as small mycelia overlapping or close to the sponge cells. When incubated in liquid medium, these fungal strains were detected 15 days after the preparation of the cytospins (36 days after the beginning of the sponge cell culture), reaching the maximum size in five additional days. However, the strains markedly reduced the growth speed after three successive subcultures, and the maximum size was reached only after 28 days.

Using primmorphs, two strains were obtained from $H$. melana, but none from $H$. heliophila (Table 1). The fungi associated with the primmorphs appeared always as small hyphae attached to the surface of the aggregates after 45 days in culture. Using whole tissue preparations, nine morphologically different strains were isolated from $H$. heliophila, although two (Hy 1 and Hy 7) could not be cultivated up to confluence. From $H$. melana whole tissue preparations, six strains were isolated and cultivated.
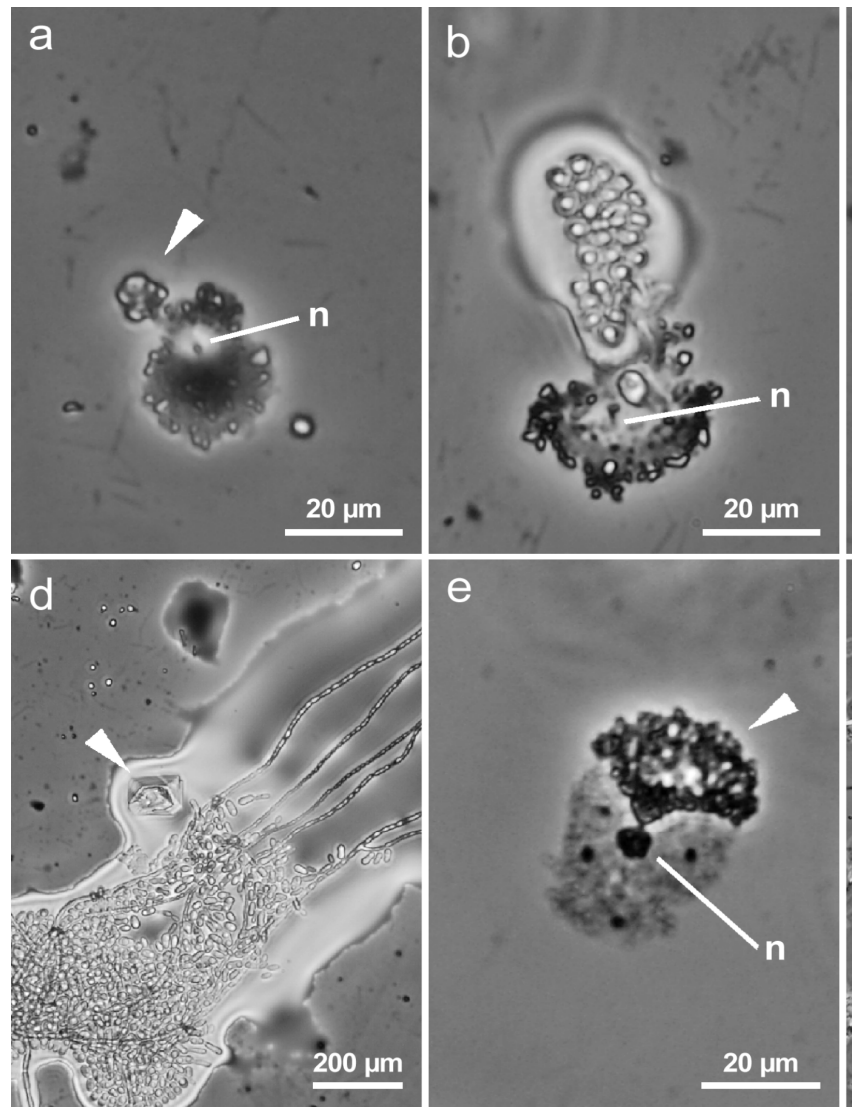

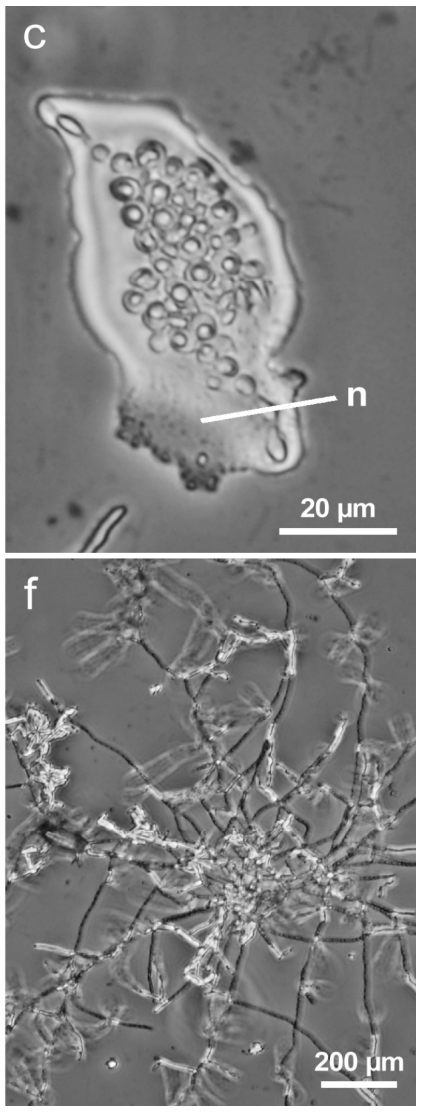

Figure 1. Growth of strains Ha IV and $\mathrm{Ha} \mathrm{V}$ from $H$. melana cells in culture. (a, b, c) Hyphae of Ha IV growing from a single sponge cell immersed in DY liquid media (b and c: same field). The deposition of insoluble hyaline material of unknown nature is already visible since the early growth stages (n: nuclei). (d) Ha IV mycelium immersed in DY liquid media, $24 \mathrm{~h}$ after the strain started to grow from the sponge cell. Large deposits of hyaline material surround the hyphae and include crystals (arrow). (e) Hyphae of Ha IV (arrow) growing from a single sponge cell. (f) Ha IV mycelium, 24h after the strain started to grow from the sponge cell. 


\section{Fungal identification}

The tentative fungal identifications based on the NCBI database best matches and accession numbers for the strains obtained in this work are summarized in Table 1. All fungi isolated from whole tissue preparations from both sponges belong to the genus Penicillium, with the only exception of one strain related to Emericella nidulans (AB008403) in $H$. melana. In contrast, this genus was poorly represented in the material obtained from cell cultures, with only one strain $(\mathrm{Ha}$
VII) found in H. melana (Penicillium sp. YW01. GU944770). In both sponges, all strains obtained from cell-derived material were distinct from those isolated from whole tissue preparations of the same individual. In addition, different cellderived strains were obtained from each sponge species. Phylogenetic trees inferred with the partial 18S rRNA sequences showed that all cell-derived strains are related (Fig. 2), with the exception of Ha VII (Penicillium sp. YW01).

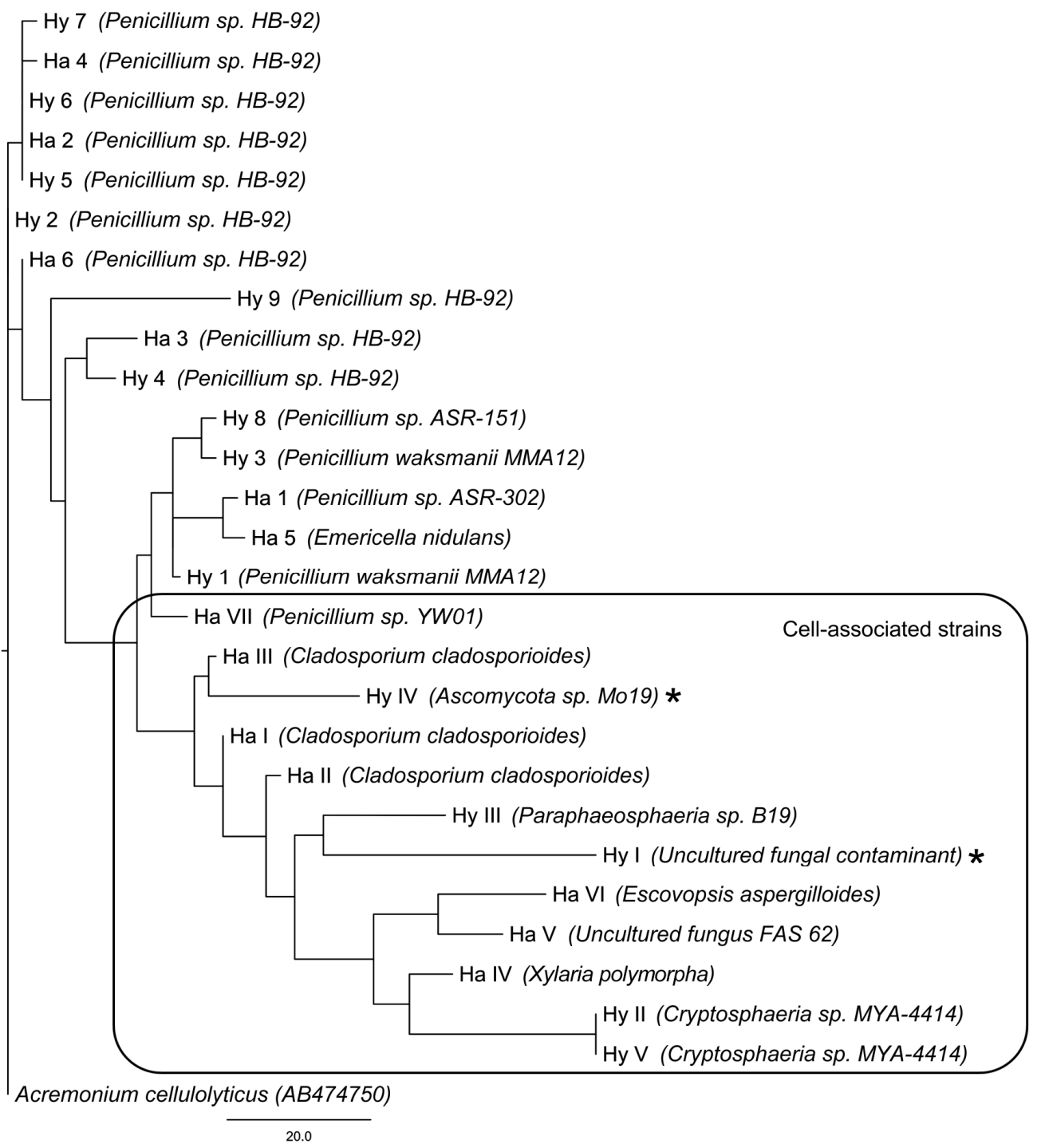

Figure 2. Phylogenetic tree depicting the relationship among the strains isolated from whole tissue and cell culture preparations of H. heliophila $(\mathrm{Hy})$ and $H$. melana $(\mathrm{Ha})$. The GenBank best matches sequences are given (asterisks: strains obtained from marine sources). 


\section{DISCUSSION}

Among all marine Phyla, Porifera is regarded as one of the most important sources of metabolite-producing fungi $(26,36)$, and in the last decade have increasingly become the target in the search for new strains with biotechnological potential (14, 27). Different approaches have been used to isolate and cultivate these microorganisms, mostly using whole homogenates or dissected tissue samples (e.g. 12, 22, 26, 41). Such studies have obtained a large number of different strains and increased the knowledge about the diversity of spongeassociated fungi. However, details about the mechanisms and interactions with their hosts are scarce (17), and it is probable that several strains are missed by overgrowth or competitive interference by other species. By using in vitro sponge cell cultures and single cells (cytospins), the focus in the present work was to select only those strains specifically associated with sponges.

From all fungal strains isolated from $H$. heliophila and $H$. melana, only two have best match sequences similar to fungi already obtained from marine sources (see Table 1). Thus Hy IV was related to a Ascomycota strain collected in deep sea termal vents (2), and $\mathrm{Ha} \mathrm{V}$ was similar to an uncultured marine fungus isolated from the sediment of the Arabian Sea (Jebaraj et al. unpublished). For all other strains, the best match sequences points to well known terrestrial species, most belonging to the genus Penicillium and Cladosporium. However, in recent years evidence has been accumulating that indicates the presence of these (and others) ubiquitous terrestrial fungi in the marine environment $(17,26,30)$.

Interestingly, none of the strains isolated from the in vitro cell cultures was found in the whole tissue preparations of the same animal. Moreover, the fungal communities of cellular origin of each sponge species were different. In contrast, the strains obtained from the whole tissue preparations of $H$. heliophila and $H$. melana were not species-specific, exhibiting similar microbial profiles. In this case, the dominant fungal strain was related to Penicillium, which was represented in the cell-derived cultures by only one strain (Ha VII: Penicillium sp. YW01). This dominance is reflected in the phylogenetic analysis (Fig. 2), which groups all whole tissue strains in opposition to the cell-derived lineages.

Of particular interest is the fact that two strains (Ha IV and $\mathrm{Ha} \mathrm{V}$ ) were observed directly connected to single sponge cells, appearing 15 days after the cytospins were placed in DY media and 36 days after the sponge culture. It is possible that these fungi were acquired from the original marine environment or accidentally attached to the sponge cells surface during manipulation. However, when isolated from the cytospins and inoculated in fresh DY media, they reached the maximum size in only five days. This suggests that the fungi were indeed enclosed in the sponge cells, similarly to what has been observed in Chondrilla (18), and the lapse in the initial growth time was due to a latency of the enclosed fungi. This condition would be interrupted after the sponge cell death, forcing the fungus to grow towards the nutrient medium. Moreover, after three successive subcultures the strains reduced their growth speed noticeably. This indicates lack of a putative component supplied by the sponge cells - growth factor or nutrients - and suggests a facultative dependence. A similar process could be responsible for the late appearance (45 days) of the two strains obtained from $H$. melana primmorphs. Primmorphs are three-dimensional aggregates surrounded by a continuous pinacoderm, in which the cells are fully capable of physiological processes such as allogeneic recognition $(5,43)$ and spicule secretion (3). Depending on the species, they can be kept in plain seawater without additional nutrients for several days or even months, after which they degenerate and die $(33,38)$. After 45 days in culture, the primmorphs of $H$. melana already started this declining process, and no longer maintained the initial aspect of a rounded, dense cell mass with a smooth surface. It is possible that at this stage, enclosed fungi were released from the dormancy, in the same way as observed in the isolated cells. 
The possibility that these fungi were admitted to intracellular life by means of endocytosis depends on the pathogen adaptations (28). The loss of virulence and the production of anti-phagocytosis substances would allow the initially intracellular parasite to become an endosymbiont (4, 8). Alternatively, many sponge cell types are phagocytes (29), and fungal spores could enter the cells by this process without disrupting the cell membranes. In this sense, a casual infestation followed by phagocytosis would explain why the fungi were present inside the cells and not in the whole tissue. However, it would not explain why these strains were not phagocysed and eliminated during the in vitro sponge cell culture (21 days). This would mean a partial loss in the ability to recognize non-self components, which seems unlikely. Thus, the results suggest the presence of at least two intracellular species: Ha VI and Ha VII, from H. melana, and the specificity of the other strains isolated from the single cells and primmorphs.

The identifications obtained by the best match sequences in GenBank are provisional, and can only indicated affinities of the obtained fungal strains. From all strains obtained in this work, nine from $H$. heliophila and seven from $H$. melana show sequence identity equal to or less than $98 \%$ compared to those available in GenBank, indicating some probable new species. In addition, five of these low identity strains from $H$. heliophila and four from the $H$. melana were obtained directly from sponge cells in culture. At this point, additional data, such as linking morphological observations with a more comprehensive molecular analysis is necessary to ensure the correct identification. Nonetheless, this is the first report of fungal strains isolated using in vitro sponge cell cultures, and one can imagine that similar approach can be used for other microorganisms such as bacteria. Our data show that primmorphs and even single cells can be used as the initial material for cultures, allowing detailed observation of the emergence and growth of specific strains and the selection of those that are not obtainable by usual techniques.

\section{ACKNOWLEDGEMENTS}

This work was funded by the Conselho Nacional de Desenvolvimento Científico e Tecnológico and the Bundesministerium für Bildung und Forschung (GermanBrazilian Cooperation in Marine Sciences - $\mathrm{CNPq}$ 590004/2005-0; BMBF 03F0451). The authors thank Dr. Fernando P.L. Marques (Departamento de Zoologia. IB/USP) for the assistance with the phylogenetic analysis.

\section{REFERENCES}

1. Blunt, J.W.; Copp, B.R.; Hu, W.P.; Munro, M.H.G.; Northcote, P.T.; Prinsep, M.R. (2009). Marine natural products. Nat. Prod. Rep. 26, 170244.

2. Burgaud, G.; Le Calvez, Th.; Arzur, D.; Vandenkoornhuyse, Ph.; Barbier, G. (2009). Diversity of culturable marine filamentous fungi from deep-sea hydrothermal vents. Environ. Microbiol. 11, 1588-1600.

3. Cao, X.; Fu, W.; Yu, X.; Zhang, W. (2007). Dynamics of spicule production in the marine sponge Hymeniacidon perlevis during in vitro cell culture and seasonal development in the field. Cell. Tiss. Res. 329, 595-608.

4. Corsaro, D.; Venditti, D.; Padula, M.; Valassina, M. (1999). Intracellular Life. Crit. Rev. Microbiol. 25, 39-79.

5. Custódio, M.R.; Hajdu, E.; Muricy, G. (2002). In vivo study of microsclere formation in sponges of the genus Mycale (Demospongiae, Poecilosclerida). Zoomorphology 121, 203-211.

6. Custódio, M.R.; Hajdu, E.; Muricy, G. (2004). Cellular dynamics of in vitro allogeneic reactions of Hymeniacidon heliophila (Demospongiae: Halichondrida). Mar. Biol. 144, 999-1010.

7. Dugan, F.M. (2006). The identification of fungi. American Phytopathological Society Press, Saint Paul.

8. Goebel, W.; Gross, R. (2001). Intracellular survival strategies of mutualistic and parasitic prokaryotes. TRENDS Microbiol. 9, 267-274.

9. Hentschel, U.; Usher, K.M.; Taylor, M.W. (2006). Marine sponges as microbial fermenters. FEMS Microbiol. Ecol. 55, 167-177.

10. Hooper, J.N.A.; van Soest, R.W.M. (2002). Systema Porifera: a guide to the classification of sponges. Kluwer Academic/Plenum Publishers, New York.

11. Huang, X.; Madan, A. (1999). CAP3, A DNA sequence assembly program. Genome Res. 9, 868-877.

12. Kennedy, J.; Codling, C.; Jones, B.; Dobson, A.; Marchesi, J. (2008). Diversity of microbes associated with the marine sponge, Haliclona simulans, isolated from Irish waters and identification of polyketide 
synthase genes from the sponge metagenome. Environ. Microbiol. 10, 1888-1902.

13. Kohlmeyer, J. (1984). Tropical marine fungi. Mar. Ecol. 5, 329-378.

14. König, G.; Kehraus, S.; Seibert, S.; Abdel-Lateff, A.; Müller, D. (2006). Natural products from marine organisms and their associated microbes. ChemBioChem 7, 229-238.

15. Lang, G.; Wiese, J.; Schmaljohann. R.; Imhoff, J. (2007). New pentaenes from the sponge-derived marine fungus Penicillium rugulosum: structure determination and biosynthetic studies. Tetrahedron 63, 11844-11849.

16. Lee, Y.; Lee, J.; Lee, H. (2001). Microbial symbiosis in marine sponges. J. Microbiol. 39, 254-264.

17. Li, Q.; Wang, G. (2009). Diversity of fungal isolates from three Hawaiian marine sponges. Microbiol. Res. 164, 233-241.

18. Liu, W.C.; Li, C.Q.; Zhu, P.; Yang, J.L.; Cheng, K.D. (2009). Phylogenetic diversity of culturable fungi associated with two marine sponges: Haliclona simulans and Gelliodes carnosa, collected from the Hainan Island coastal waters of the South China Sea. Fungal Divers. 42 (1), 1-15.

19. Maldonado, M.; Cortadella, N.; Trilla, M.I.; Rützler, K. (2005), Endosymbiotic yeast maternally transmitted in a marine sponge. Biol. Bull. 209, 94-106.

20. Müller, W.E.G. (1998). Origin of Metazoa: sponges as living fossils. Naturwissenschaften 85, 11-25.

21. Muricy, G.; Hajdu, E. (2006) Porifera Brasilis: Guia de identificação das esponjas marinhas mais comuns do Sudeste do Brasil. Museu Nacional. Série Livros 17. Rio de Janeiro.

22. Paz, Z.; Komon-Zelazowska, M.; Druzhinina, I.S.; Aveskamp, M.M.; Shnaiderman, A.; Aluma, Y.; Carmeli, S.; Ilan, M.; Yarden, O. (2010). Diversity and potential antifungal properties of fungi associated with a Mediterranean sponge. Fungal Divers. 42, 17-26.

23. Pfannkuchen, M.; Fritz, G.B.; Schlesinger, S.; Bayer, K.; Brümmer, F. (2009). In situ pumping activity of the sponge Aplysina aerophoba, Nardo 1886. J. Exp. Mar. Biol. Ecol. 369, 65-71.

24. Pile, A.J.; Patterson, M.; Witman, J. (1996). In situ grazing on plankton $<10$ microns by the boreal sponge Mycale lingua. Mar. Ecol. Prog. Ser. 141, 95-102.

25. Pile, A.J.; Young, C.M. (2006). The natural diet of a hexactinellid sponge: benthic-pelagic coupling in a deep-sea microbial food web. Deep-Sea Res. 53, 1148-1156.

26. Proksch, P.; Ebel, R.; Edrada, R.; Riebe, F.; Liu, H.; Diesel, A.; Bayer, M.; Li, X.; Lin, W.H.; Grebenyuk, V.; Müller, W.E.G.; Draeger, S.; Zuccaro, A.; Schulz, B. (2008). Sponge-associated fungi and their bioactive compounds: the Suberites case. Bot. Mar. 51, 209-218.

27. Raghukumar, C. (2008). Marine fungal biotechnology: an ecological perspective. Fungal Divers. 31, 19-35.

28. Selvin, J.; Ninawe, A.S, Kiran, G.S, Lipton, A. P. (2010). Spongemicrobial interactions: Ecological implications and bioprospecting avenues. Crit. Rev. Microbiol. 36, 82-90

29. Simpson, T.L. (1984). The cell biology of sponges. Springer-Verlag, New York.

30. Singh, P.; Raghukumar, C.; Verma, V.; Souche, Y. (2010). Phylogenetic diversity of culturable fungi from the deep-sea sediments of the Central Indian Basin and their growth characteristics. Fungal Divers. 40, 89-102.

31. Sipkema, D.; Franssen, M.C.R.; Osinga, R.; Tramper, J.; Wijffels, R.H. (2005). Marine sponges as pharmacy. Mar. Biotechnol. 7, 142-162.

32. Sipkema, D.; Holmes, B.; Nichols, S.A.; Blanch, H.W. (2009). Biological characterization of Haliclona (?gellius) sp.: sponge and associated microorganisms. Microb. Ecol. 58, 903-920.

33. Sipkema, D.; Van Wielink, R.; Van Lammeren, A.A.M.; Tramper, J.; Osinga, R.; Wijffels, R.H. (2003). Primmorphs from seven marine sponges: formation and structure. J. Biotech. 100, 127-139.

34. Smit, E.; Leeflang, P.; Glandorf, B.; Van Elsas, J.; Wernars, K. (1999). Analysis of fungal diversity in the wheat rhizosphere by sequencing of cloned PCR-amplified genes encoding 18s rRNA and temperature gradient gel electrophoresis. Appl. Environ. Microbiol. 65, 2614-2621.

35. Thakur, N.L.; Anil, A.C.; Müller, W.E.G. (2004). Culturable epibacteria of the marine sponge Ircinia fusca: temporal variations and their possible role in the epibacterial defense of the host. Aquat. Microb. Ecol. 37, 295304

36. Thomas, T.R.A.; Kavlekar, D.P.; LokaBharathi, P.A. (2010). Marine drugs from sponge-microbe association: a review. Mar. Drugs 8, $1417-$ 1468 .

37. Vacelet, J.; Duport, E. (2004). Prey capture and digestion in the carnivorous sponge Asbestopluma hypogea (Porifera: Demospongiae). Zoomorphology 123, 179-190.

38. Valisano, L.; Bavestrello, G.; Giovine, M.; Cerrano, C. (2006). Primmorphs formation dynamics: a screening among Mediterranean sponges. Mar. Biol. 149, 1037-1046.

39. Varon, A.; Le Sy, V.; Wheeler, W.C. (2010). POY version 4, phylogenetic analysis using dynamic homologies. Cladistics 26 (1), 72 85.

40. Wang, G. (2006). Diversity and biotechnological potential of the spongeassociated microbial consortia. J. Ind. Microbiol. Biotechnol. 33, 545551.

41. Wang, G.; Li, Q.; Zhu, P. (2008). Phylogenetic diversity of culturable fungi associated with the Hawaiian sponges Suberites zeteki and Gelliodes fibrosa. Antonie Leeuwenhoek 93, 163-174.

42. Webster, N.; Negri, A.; Munro, M.; Battershill, C.N. (2004). Diverse microbial communities inhabit Antarctic sponges. Environ. Microbiol. 6, 288-300.

43. Wiens, M.; Perovic-Ottstadt, S.; Müller, I.M.; Müller, W.E.G. (2004). Allograft rejection in the mixed cell reaction system of the demosponge Suberites domuncula is controlled by differential expression of apoptotic genes. Immunogenetics 56, 597-610. 